\title{
Does Oregano Protect Against Testicular Toxicity Produced by Ethylene Glycol in Adult Male Albino Rat?
}

\author{
¿El Orégano Protege Contra la Toxicidad Testicular Producida \\ por Etilenglicol en Ratas Macho Albinas Adultas?
}

\begin{abstract}
Naser A. EISawy ${ }^{1,2}$; Abdullah G Alkushi ${ }^{3}$; Wardah Abdullah Mohammed Alasmari ${ }^{3}$ : Mustafa M. Sinna ${ }^{3}$; Eslam A. Header ${ }^{4}$; Mohammad A. Elmadbouly ${ }^{4}$ \& Ashraf Mohamed Elsayed Ali Sakran ${ }^{3}$
\end{abstract}

ELSAWY, N. A.; ALKUSHI, A. G.; ALASMARI, W. A. M.; SINNA, M. M.; HEADER, E. A.; ELMADBOULY, M. A. \& SAKRAN, A. M. E. A. Does oregano protect against testicular toxicity produced by ethylene glycol in adult male albino rat? Int. J. Morphol., $37(1): 358-362,2019$

SUMMARY: Origanum vulgare Linn has traditionally been used as a diuretic and antispasmodic. Therefore, we investigated the active extract of Origanum vulgare for possible andrological effect and preventive effects against testicular damage using ethylene glycol rat model of testicular damage, to rationalize its medicinal use. Male Wistar rats received lithogenic treatment comprising of 0.75 $\%$ ethylene glycol injection twice with one day interval, then in drinking water, active extract of Origanum vulgare treatment (20 mg/kg) was given for 3 weeks to prevent toxic damage including loss of body weight gain and appetite, Following oral administration of EGME, a rapid decrease in testis weight associated with testicular cell damage was observed. Origanum vulgare treatment (20 mg/kg) prevented as well as reversed toxic changes including loss of body weight gain.

KEY WORDS: Origanum vulgare; Ethylene glycol; Testicular damage.

\section{INTRODUCTION}

The ability of ethylene glycol mono-n-alkyl ethers to produce testicular damage has been known for some time. Wiley et al. (1938) first demonstrated the testicular effects of ethylene glycol monomethyl ether (EGME) in rabbits in 1938. Stenger et al. (1971) have shown that the monoethyl derivative (EGEE) can also induce testicular damage in dogs and rats. More recently, Nagano et al. (1979), using a variety of ethylene glycol monoalkyl ethers in studies with orally treated mice, have shown EGME, ethylene glycol monomethyl ether acetate (EGMEA) and EGEE to be the most potent of the series examined in producing adverse testicular effects. EGME has also been shown to produce a decrease in testicular weight in the rat and mouse following inhalation exposure for 2 weeks at $1000 \mathrm{ppm}$.

Glycolic acid is the major metabolite of ethylene glycol responsible for toxicity (Barceloux et al., 1999). The toxic mechanism of ethylene glycol poisoning is mainly due to the metabolites of ethylene glycol. Initially it is metabolized by alcohol dehydrogenase to glycolaldehyde, which is then oxidized to glycolic acid (Maier, 1983). The metabolic effects occur 12 to 36 hours post ingestion, causing primarily metabolic acidosis which is due mainly to accumulated glycolic acid. Additionally, as a side effect of the first two steps of metabolism, an increase in the blood concentration of lactic acid occurs contributing to lactic acidosis. The formation of acid metabolites also causes inhibition of other metabolic pathways, such as oxidative phosphorylation. The ratelimiting step in this cascade is the conversion of glycolic to glyoxylic acid. Accumulation of glycolic acid in the body is mainly responsible for toxicity (Brent, 2001). Ethylene glycol has been shown to be toxic to humans (Friedman $e t$ al., 1962) and is also toxic to domestic pets such as cats and dogs. A toxic dose requiring medical treatment varies but is considered more than $0.1 \mathrm{~mL}$ per kg body weight $(\mathrm{mL} / \mathrm{kg})$ of pure substance. That is roughly $16 \mathrm{~mL}$ of $50 \%$

\footnotetext{
${ }^{1}$ Department of Anatomy and Embryology, Faculty of Medicine, Zagazig University, Egypt.

${ }^{2}$ Department of Laboratory Medicine, Faculty of Applied Medical Sciences, Umm Al-Qura University, Saudi Arabia.

${ }^{3}$ Department of Anatomy, Faculty of Medicine, Umm Al-Qura University, Saudi Arabia.

${ }^{4}$ Clinical Nutrition Department, Faculty of Applied Medical Sciences, Umm Al-Qura University, Saudi Arabia.
} 
ELSAWY, N. A.; ALKUSHI, A. G.; ALASMARI, W. A. M.; SINNA, M. M.; HEADER, E. A.; ELMADBOULY, M. A. \& SAKRAN, A. M. E. A. Does oregano protect against testicular toxicity produced by ethylene glycol in adult male albino rat? Int. J. Morphol., 37(1):358-362, 2019.

ethylene glycol for an $80 \mathrm{~kg}$ adult and $4 \mathrm{~mL}$ for a $20 \mathrm{~kg}$ child. Poison control centers often use more than a lick or taste in a child or more than a mouthful in an adult as a dose requiring hospital assessment (Caravati et al., 2005). The orally lethal dose in humans has been reported as approximately $1.4 \mathrm{~mL} / \mathrm{kg}$ of pure ethylene glycol (Friedman et al.). That is approximately $224 \mathrm{~mL}$ of $50 \%$ ethylene glycol for an $80 \mathrm{~kg}$ adult and $56 \mathrm{~mL}$ for a $20 \mathrm{~kg}$ child. Although survival with medical treatment has occurred with doses much higher than this, death has occurred with $30 \mathrm{~mL}$ of the concentrate in an adult (Amathieu et al., 2006). In the EU classification of dangerous substances it is 'harmful' (Xn) while more toxic substances are classified as 'toxic' (T) or 'very toxic' (T+). The U.S. Environmental Protection Agency generally puts substances which are lethal at more than $30 \mathrm{~g}$ to adults in Toxicity Class III. Ethylene glycol has a low vapor pressure; it does not evaporate readily at normal temperatures and therefore high concentrations in air or intoxication are unlikely to occur following inhalational exposures (Hodgman et al., 1997). There may be a slight risk of poisoning where mists or fogs are generated, although this rarely leads to poisoning as ethylene glycol causes irritation and coughing when breathed in, alerting victims to its presence (Wills et al., 1974). Ethylene glycol is not well absorbed through skin meaning poisoning following dermal exposure is also uncommon (Driver et al., 1993).

Origanum vulgare Linn (family, Lamiaceae) is distributed throughout Asia, Europe and North America and is commonly known as Wild Marjoram and Winter Sweet and locally in Pakistan as Mirzanjosh, Sathra. It is widely used in the traditional medicine as lithotriptic, diuretic and antispasmodic along with other medicinal uses, such as stimulant, expectorant, antibacterial, anticancer, anti-inflammatory, antioxidant and laxative (Lemhadri et al., 2004).

Oregano is a light green in color with strong aromatic odor and pleasantly bitter taste Oregano goes well with tomato sauces, pizza and vegetables (Gilani et al., 2005). Some researches provides evidence that oregano improves growth in growth retarded animals and has no specific immunostimulatory effects on porcine immune cells (Williamson, 2001). Origanum vulgare Linn (family, Lamiaceae) is distributed throughout Asia, Europe and North America and is commonly known as Wild Marjoram and Winter Sweet and locally in Pakistan as Mirzanjosh (PDR for Herbal Medicines, 2000). It is widely used in the traditional medicine as lithotriptic, diuretic and antispasmodic along with other medicinal uses, such as stimulant, expectorant, antibacterial, anticancer, antiinflammatory, antioxidant and laxative (Duke, 2002).

\section{MATERIAL AND METHOD}

The materials used for this experiment are as follows: OHAUS electric weighing balance, Teflon Pyrex tissue ground, Soxhlet apparatus, thimble, extractor, bolt head flask, water bath, condenser, animal cages, hemocytometer, Electronic microscope, Test tubes, measuring cylinder, light microscope, desiccator.

Chemicals and Reagents: Anhydrous sodium sulphate, n-hexane, normal saline solution, ethanol, distilled water, formalin, chloroform, eosin, blue in scott's tap water.

Animals: The present study included (50) sexually active albino rats of weight between 250-280 g. The animals were obtained from the Animal House of Zagazig University Egypt. The animals were kept in the Animal House in experimental room for one week prior to the commencement of study, for acclimatization to experimental conditions with $12 \mathrm{~h}$ light and dark cycle. The animals was fed ad libitum with commercially prepared rat feeds made up of $21 \%$ protein, $3.5 \%$ fat, $6 \%$ fiber, $0.8 \%$ phosphorus and given fresh water. All the experimental procedures were done following the experimental guidelines of the institutional ethics committee on the care and use of laboratory animals.

Preparation of plant extracts: Origanum vulgare leaves were bought from Sekam company for medicinal plant (Cairo, Egypt) and identified by taxonomist The aerial part of the plant material was cleaned of adulterants and kept soaked for three days in the aqueous-ethanol (30:70) with occasional shaking, at room temperature. The filtration was carried out using a muslin cloth and then through Whatman qualitative grade 1 filter paper. This procedure was repeated twice and then all the filtrates obtained were combined and concentrated on a rotary evaporator (RE111, Buchi, Flawil, Switzerland) accompanied with B-700 recirculation chiller and a water bath model 461 at $65^{\circ} \mathrm{C}$ under vacuum. Finally, the extract change to a thick pasty mass called as crude extract (Ov.Cr), yielding approximately $12 \%$ which reconstituted in distilled water $(100 \mathrm{mg} / \mathrm{ml})$ to be used in the study.

Preliminary phytochemical analysis: The crude extract of Origanum vulgare, was screen for the presence of different phytochemical groups such as alkaloids, saponins, coumarins, sterols, terpenes, tannins and flavonoids by using different methods of extract: Group A:Ethanolic extract. Group B:Aquous extract. Group C: Ethyl acetate extract. Group D:Hexan extract (Sarac \& Ugur, 2008). 


\section{Experimental Protocol}

Five groups with 10 rats were selected randomly in each group. Groups from 2-5 were the test groups, while group 1 was used as a control. Group one was fed with $5 \mathrm{ml}$ $/ \mathrm{kg}$ ) orally of distilled water using a poly-ethene catheter while group two, three, four and five were giving $0.5 \mathrm{ml}$ of $0.75 \%$ ethylene glycol injection twice with one day interval then ethylene glycol EG $(0.75 \%) 50 \mathrm{mg} / \mathrm{kg} /$ day: Group 2 Control positive \{untreated received oral feeding of ethylene glycol EG $(0.75 \%)$ treatment for 14 days by stomach tube (1 $\mathrm{ml} / \mathrm{kg}$ ), Group 3 Treated group of extract A received oral feeding of ethylene glycol EG $(0.75 \%)$ treatment and extract A in a dose of $20 \mathrm{mg} / \mathrm{Kg}(5 \mathrm{ml} / \mathrm{kg}$ ) orally for 14 days. Group 4 Treated group of extract $B$ received oral feeding of ethylene glycol EG $(0.75 \%)$ treatment and extract B in a dose of 20 $\mathrm{mg} / \mathrm{Kg}(5 \mathrm{ml} / \mathrm{kg})$ orally for 14 days. Group 5 Treated group of extract $\mathrm{C}$ received oral feeding of ethylene glycol EG $(0.75$ $\%)$ treatment and extract C in a dose of $20 \mathrm{mg} / \mathrm{Kg}(5 \mathrm{ml} / \mathrm{kg})$ orally for 14 days.

Sample Collection. The animals were anesthetized by deep ether anaesthesia and then sacrificed. Orchiectomy was performed by open castration method. A pre-scrotal incision was made and the testicles was milked out of the incision site and weighed with the aid of OHAUS electric weighing balance. The testicles were exposed by incising the tunica vaginalis. The spermatic cord was exposed, ligated and incised. Semen samples were thereafter collected from the caudal epididymis. The method of collection was similar to that described by Olugbenga \& Oniovosa (2005).

Sperm count and motility assay: Immediately after dissection, the epididymal contents was dropped on a glass slide and viewed under the light microscope to determine the motile and non-motile sperm cells. The motile and nonmotile sperm cells were distinguished by the movement of sperm cells (WHO, 1992). The spermatozoa was counted by hemocytometer using the improved Neubauer (Deep 1/ $10 \mathrm{~mm}$, LABART, Germany) chamber as described by Pant \& Srivastava (2003).
Histological procedure. After extracting the testes from the animal's body, the organ was promptly and adequately treated with $10 \%$ formal saline (fixation) in other to preserve its structure and molecular composition. The sections were floated on water, transferred to a glass slide and stained with heamatoxylin and eosin stains with the aid of the Leica auto stainer XL. The slide was then viewed under a light microscope with varying magnification. Spermatogenesis was assessed by a method which depends upon scoring 'cross sectional' profiles of seminiferous tubules according to Johnson, using Johnson's score. For each testis, five vertical sections from the polar and the equatorial regions were sampled and an unbiased numerical estimation of the following morphometric parameters was determined using a systematic random scheme; The diameter of seminiferous tubules with profiles that were round or nearly round were measured for each animal and a mean, D, was determined by taking the average of two diameters, D1 and D2 (Perpendicular to one another). D1 and D2 were taken only when D1/D2 $\leq 0.85$, others include epithelial height, testicular weight, sustentacular cells (Sertoli cells) to germ cell ratio (elongated spermatids) (Qin \& Lung, 2002). Tissues were fixed for $24 \mathrm{hr}$ and processed into paraffin wax. Sections were stained with hematoxylin and eosin and with periodic acid-Schiff technique for the demonstration of the spermatid acrosome and definition of the stages of spermatogenesis was based on that used by Leblond \& Clermont (1952).

\section{RESULTS}

The control negative group (200x; H\&E) has normal cyto-architecture, reveal interstitial tissues (IT) and seminiferous tubules (ST) with sustentacular cells and the normal developing germ cells: spermatogonia (Sp), spermatocytes I (SPI), spermatids (Spt), spermatozoa (Spz) with flagellum. In addition to that no sloughing of the germinal epithelium and the lumen of the epithelium remained patent and intact (Fig. 1).

Table I. Androgenic parameters.

\begin{tabular}{|c|c|c|c|c|c|}
\hline Parameters & Control & Group 2 & Group3 & Group 4 & Group 5 \\
\hline S perm Motility (\%) & $54.1 \pm 2.3$ & $30 \pm 2.4$ & $45.8 \pm 1.6$ & $43.1 \pm 1.3$ & $48 \pm 1.6$ \\
\hline S perm count $($ x 106/ml) & $19.5 \pm 0.5$ & $13.1 \pm 6,1$ & $18.6 \pm 0.5^{*}$ & $19,2 \pm 3.4 * *$ & $17 \pm 0.5$ \\
\hline Sustentac ular to Spermatid ratio & $8.1 \pm 0.2$ & $1.8 \pm 0.9$ & $5.9 \pm 0.9$ & $7.1 \pm 0 . .^{4^{* *}}$ & $5.6 \pm 0.5$ \\
\hline Johnsen's score & $8.1 \pm 0.9$ & $4.5 \pm 0.3$ & $6.8 \pm 0.21$ & $7.0 \pm 0.6^{*}$ & $5.8 \pm 0.2$ \\
\hline S eminifero tub dia $(\mu \mathrm{m})$ & $344.2 \pm 9.9$ & $154.3 \pm 10$ & $269.4 \pm 13.8$ & $302.4 \pm 7^{* *}$ & $245 \pm 12$ \\
\hline Height of Epith $(\mu \mathrm{m})$ & $189 \pm 7.2$ & $66.9 \pm 6$ & $133.6 \pm 13 *$ & $161 \pm 1.4^{* *}$ & $154 \pm 9 *$ \\
\hline Testicular Weight (g) & $1.42 \pm 0.07$ & $0.9 \pm 0.3$ & $1.2 \pm 0.7$ & $1.3 \pm 0.2^{* *}$ & $1.2 \pm 0.5$ \\
\hline
\end{tabular}




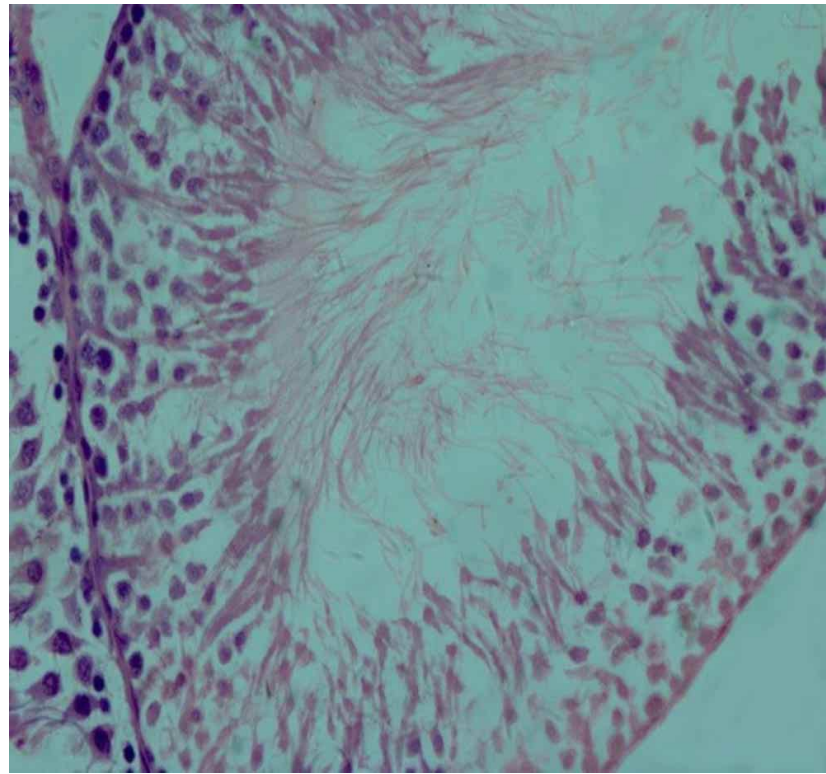

Fig. 1. Testis of rat from group 1 showing the normal histological structure of seminiferous tubules, normal spermatogenesis (stage VIII tubule). The seminiferous tubule shows a clear lumen and a normal arrangement of cellular types. Sperm tails are clearly seen (H\&E; X200).

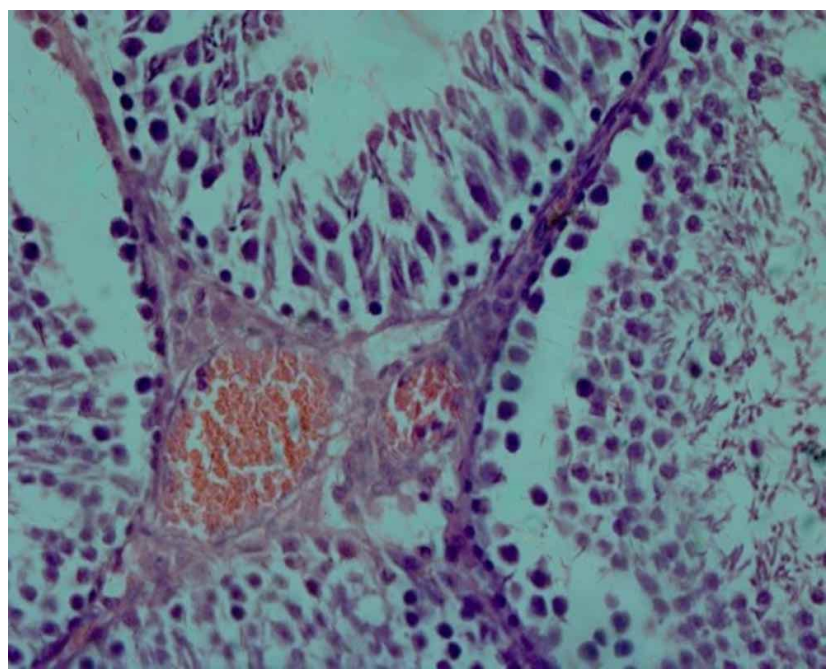

Fig. 2. Testis of rat from group 2 showing the abnormal histological structures of seminiferous tubules both germ cells and seminiferous epithelia vacuolation. Few sperms are seen in the tubule $(H \& E$; X200).

In control positive group 2 shows closely packed small round abnormal spermatocyte massive decrease of spermatozoa within the lumen of seminiferous tubule, complete absence of sustentacular cells and secondary spermatocytes included cytoplasmic vacuolation (Fig. 2).

Group 3, Group 4 \& Group 5 shows seminiferous tubules with few spermatozoa and interstitial space with interstitial cells (Leydig cells) shows presence of few sperm



Fig. 3. Testis of rat from group 3 showing seminiferous tubules with few spermatozoa, sperm and interstitial cells in EGME Treatment (H\&E; X200).

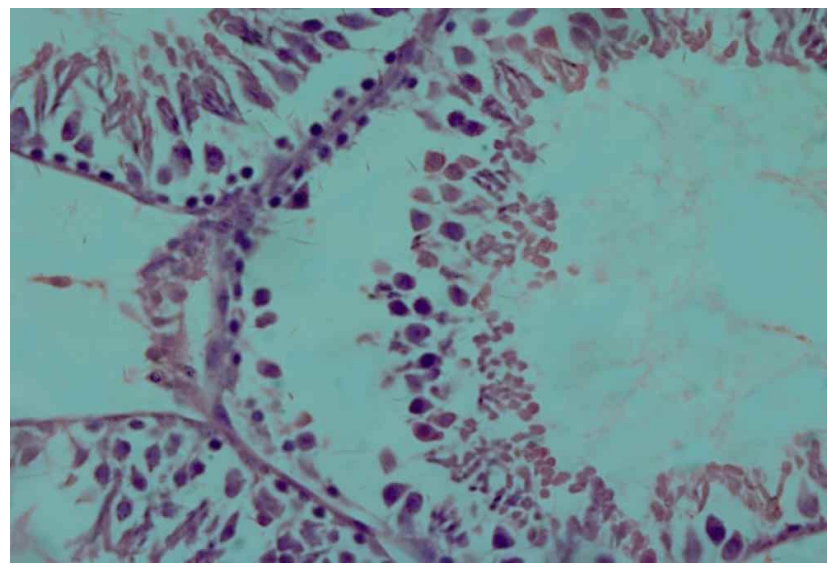

Fig. 4. Testis of rat from group 4 showing no histopathological changes (H\&E; X400).



Fig. 5. Testis of rat from group 5 showing no histopathological changes (H\&E; X400).

cell within the lumen of the seminiferous tubules vascular interstitial cells due to vascular interstitial cell moving spermatozoa along the lumen of the tubules EGME Treatment (Fig. 3-5). 


\section{DISCUSSION}

Following oral administration of EGME, a rapid decrease in testis weight associated with testicular cell damage was observed. Prolonged dosing resulted in continued spermatocyte degeneration as well as maturation depletion of the spermatid population, leaving tubules containing only sustentacular cells, spermatogonia and preleptotene spermatocytes. Although zygotene spermatocytes showed slight degeneration with prolonged exposure to high doses, maturation arrest was evident by the increased numbers of cells present. Arrest of spermatocytes at this stage indicated a failure of the cells to accomplish successful transition from zygotene to pachytene. At the ultrastructural level the mitochondria of the spermatocytes showed early evidence of disruption. Cessation of treatment indicated that the testicular lesion was reversible in the large majority of tubules. Testis weights returned to control values and the majority of tubules regained full spermatogenesis and spermatozoa production within one full spermatogenic maturation cycle (7-8 weeks in the rat). The presence of a small proportion of totally atrophic tubules indicated a loss of spermatogonia, as the mitotic component of spermatogenesis and the main germ cell type not protected by the blood-testis barrier (BTB), are the most vulnerable to toxic effects (Meistrich, 1986). Effects of toxic compounds on the testis may be reversible following cessation of compound exposure through seminiferous epithelial reconstitution from surviving stem cell spermatogonia. However, there is variability across different classes of toxic compounds, stem cell proliferation is slow, and in humans it may take months to years for sperm production to recover (Roeser et al., 1978).

ELSAWY, N. A.; ALKUSHI, A. G.; ALASMARI, W. A. M.; SINNA, M. M.; HEADER, E. A.; ELMADBOULY, M. A. \& SAKRAN, A. M. E. A. ¿El orégano protege contra la toxicidad testicular producida por etilenglicol en ratas macho albinas adultas? Int. J. Morphol., 37(1):358-362, 2019.

RESUMEN: Origanum vulgare Linn se ha usado tradicionalmente como diurético y antiespasmódico. Por lo tanto, investigamos el extracto activo de Origanum vulgare por su posible efecto andrológico y efectos preventivos contra el daño testicular utilizando el modelo de rata de etilenglicol de daño testicular. El objetivo del estudio fue racionalizar su uso medicinal. Su utilizaron ratas Wistar macho que recibieron un tratamiento litogénico de una inyección de etilenglicol al 0,75\%, dos veces con un intervalo de un día, y luego se administró en agua potable. Se administró el extracto activo del tratamiento con Origanum vulgare $(20 \mathrm{mg} / \mathrm{kg}$ ) durante 3 semanas con el objetivo de prevenir el daño tóxico, la pérdida de peso corporal y el apetito. Tras la administración oral de EGME, se observó una rápida disminución del peso de los testículos asociada al daño de las células testiculares. El tratamiento con Origanum vulgare ( $20 \mathrm{mg} / \mathrm{kg}$ ) logró prevenir y revertir las alteraciones tóxicas, incluyendo la pérdida de peso corporal.

PALABRAS CLAVE: Origanum vulgare; Etilenglicol; Daño testicular.

\section{REFERENCES}

Amathieu, R.; Merouani, M.; Borron, S. W.; Lapostolle, F.; Smail, N. \& Adnet, F. Prehospital diagnosis of massive ethylene glycol poisoning and use of an early antidote. Resuscitation, 70(2):285-6, 2006.

Barceloux, D. G.; Krenzelok, E. P.; Olson, K. \& Watson, W. American Academy of Clinical Toxicology Practice Guidelines on the Treatment of Ethylene Glycol Poisoning. Ad Hoc Committee. J. Toxicol. Clin. Toxicol., 37(5):537-60, 1999.

Brent, J. Current management of ethylene glycol poisoning. Drugs, 61 (7):979-88, 2001 Caravati, E. M.; Erdman, A. R.; Christianson, G.; Manoguerra, A. S.; Booze, L. L.; Woolf, A. D.; Olson, K. R.; Chyka, P. A.; Scharman, E. J.; Wax, P. M.; Keyes, D. C. Troutman, W. G. \& American Association of Poison Control Centers. Ethylene glycol exposure: an evidence-based consensus guideline for out-of-hospital management. Clin. Toxicol. (Phila.)., 43(5):327-45, 2005.

Driver, J.; Tardiff, R. G.; Sedik, L.; Wester, R. C. \& Maibach, H. I. In vitro percutaneous absorption of [14C] ethylene glycol. J. Expo. Anal. Environ. Epidemiol., 3(3):27784, 1993.

Duke, J. A. Handbook of Medicinal Herbs. Boca Raton, CRC Press, 2002.

Friedman, E. A.; Greenberg, J. B.; Merrill, J. P. \& Dammin, G. J. Consequences of ethylene glycol poisoning. Report of four cases and review of the literature. Am. J. Med., 32(6):891-902, 1962

Gilani, A. H. \& Rahman, A. U. Trends in ethnopharmocology. J. Ethnopharmacol., 100(12):43-9, 2005.

Hodgman, M. J.; Wezorek, C. \& Krenzelok, E. Toxic inhalation of ethylene glycol: a pharmacological improbability. J. Toxicol. Clin. Toxicol., 35(1):109-11, 1997.

Leblond, C. P. \& Clermont, Y. Definition of the stages of the cycle of the seminiferous epithelium in the rat. Ann. N. Y. Acad. Sci., 55(4):548-73, 1952.

Lemhadri, A.; Zeggwagh, N. A.; Maghrani, M.; Jouad, H. \& Eddouks, M. Antihyperglycaemic activity of the aqueous extract of Origanum vulgare growing wild in Tafilalet region. J. Ethnopharmacol., 92(2-3):251-6, 2004.

Maier, W. Cerebral computed tomography of ethylene glycol intoxication. Neuroradiology, 24(3):175-7, 1983

Meistrich, M. L. Critical components of testicular function and sensitivity to disruption. Biol Reprod., 34(1):17-28, 1986.

Nagano, K.; Nakayama, E.; Koyano, M.; Oobayashi, M.; Adachi, H. \& Yamada, T. Testicular atrophy of mice induced by ethylene glycol mono alkyl ethers (author's transl). Sangyo Igaku, 21(1):29-35, 1979

Olugbenga, O. M. \& Oniovosa, U. Spermiogram and morphological characteristics in testicular and epididymal spermatozoa of large white boar in Nigeria. Int. J. Morphol., 23(3):235-9, 2005 .

Pant, N. \& Srivastava, S. P. Testicular and spermatotoxic effects of quinalphos in rats. $J$. Appl. Toxicol,. 23(4):271-4, 2003.

PDR for Herbal Medicines. Montvale, Medical Economics Company, 2000.

Qin, D. N. \& Lung, M. A. Morphometric study on leydig cells in capsulotomized testis of rats. Asian J. Androl., 4(1):49-53, 2002.

Roeser, H. P.; Stocks, A. E. \& Smith, A. J. Testicular damage due to cytotoxic drugs and recovery after cessation of therapy. Aust. N. Z. J. Med., 8(3):250-4, 1978.

Sarac, N. \& Ugur, A. Antimicrobial activities of the essential oils of Origanum onites L., Origanum vulgare L. subspecies hirtum (Link) Ietswaart, Satureja thymbra L., and Thymus cilicicus Boiss. \& Bal. growing wild in Turkey. J. Med. Food, 11(3):568-73, 2008.

Stenger, E. G.; Aeppli, L.; Miller, D.; Peheim, E. \& Thomann, P. Zur Toxikologie des Aethyleneglykol-monoathylathers. Arzneim. Forsch., 21:880-5, 1971.

Wiley, F. H.; Hueper, W. C. \& Bergen, D. S. The formation of oxalic acid from ethylene glycol and related solvents. J. Indian Hyg. Toxicol., 20:269-77, 1938.

Williamson, E. M. Synergy and other interactions in phytomedicines. Phytomedicine, 8(5):401-9, 2001.

Wills, J. H.; Coulston, F.; Harris, E. S.; McChesney, E. W.; Russell, J. C. \& Serrone, D. M. Inhalation of aerosolized ethylene glycol by man. Clin. Toxicol., 7(5):463-76, 1974.

Corresponding author:

Abdullah G Alkushi

Department of Anatomy

Faculty of Medicine

Umm Al-Qura University

SAUDI ARABIA

Received: 06-09-2018

Accepted: 20-11-2018

Email: dr.alkushi@gmail.com 